\title{
MAGIS DAN ASPEK KELEGAAN JIWA BERDASARKAN PERSPEKTIF EMOSI HAIRAN DALAM HIKAYAT MARAKARMAH
}

\author{
${ }^{1}$ Afidatul Syazwani Afandi, ${ }^{2}$ Norazimah Zakaria, ${ }^{3}$ Abdul Halim Ali \\ ${ }^{1}$ Universiti Malaysia Kelantan, Kampus Bachok, Beg Berkunci No.01, 16300 Bachok, Kelantan, Malaysia \\ 2, ${ }^{3}$ Fakulti Bahasa dan Komunikasi, Universiti Pendidikan Sultan Idris, 35900 Tanjung Malim, Perak, Malaysia \\ 1afidatul@umk.edu.my, ${ }^{2}$ norazimah@fbk.upsi.edu.my, ${ }^{3}$ halim.ali@fbk.upsi.edu.my
}

Received: 02 June 2020; Accepted: 04 December 2020; Published: 07 December 2020

To cite this article (APA): Afandi, A. S., Zakaria, N., \& Ali, A. H. (2020). Magis dan Aspek Kelegaan Jiwa berdasarkan Perspektif Emosi Hairan dalam Hikayat Marakarmah. Jurnal Peradaban Melayu, 15, 10-21. https://doi.org/10.37134/peradaban.vol15.2.2020

To link to this article: https://doi.org/10.37134/peradaban.vol15.2.2020

\begin{abstract}
ABSTRAK
Magis atau unsur luar biasa sering kali ditemui dalam kebanyakan teks hikayat yang mempunyai pengaruh HinduIslam. Pemaparan unsur ini dianggap penting oleh pengarang tradisi untuk dijadikan intipati kepada struktur teks klasik. Kehebatan pengarang tradisi mencakna mesej kepada khalayak melalui bauran peristiwa yang luar biasa ini membawa implikasi yang besar kepada khalayak dan meransang beberapa kesan emosi tertentu. Salah satu daripada emosi ini ialah emosi hairan yang membangkitkan rasa takjub dan kagum. Objektif kajian ini adalah untuk melihat hubung kait emosi hairan dan aspek kelegaan jiwa yang akan dikupas berdasarkan teks pilihan ini. Kaedah yang digunakan dalam kajian ini bersifat kualitatif di bawah analisis deskriptif berpusatkan teks. Huraian data dan maklumat daripada kaedah analisis tekstual ini akan dibahagikan kepada analisis yang bersifat struktural yang melihat struktur ayat dan pengolahan gaya bahasa yang berupaya mewujudkan emosi hairan dan rasa takjub serta analisis yang bersifat teoritikal yang melihat aspek emosi ini daripada perspektif rasa fenomenologi sekali gus mengaitkan emosi hairan dan kesan rasa takjub ini dengan aspek kelegaan jiwa. Hasil analisis mendapati, sememangnya terdapat beberapa peristiwa di dalam teks Hikayat Marakarmah yang meransang emosi hairan dan rasa takjub serta berupaya memberikan kesan kelegaan jiwa kepada khalayak. Implikasi daripada kajian ini merumuskan emosi hairan yang menerbitkn rasa kagum khalayak kepada kebanyakan peristiwa magis yang terdapat dalam teks Hikayat Marakarmah ini menimbulkan kesan rasa lega sekali gus membuktikan kehebatan pengarang tradisi mengadun aspek estetika dan mesej yang hendak disampaikan secara tersirat.
\end{abstract}

Kata Kunci: Magis, Emosi, Hairan, Takjub, Estetika dan Kelegaan Jiwa

\begin{abstract}
Magical or supernatural elements are often found in many hikayat (epic tales) texts with Hindu-Islamic influences. The depiction of this element is considered important by traditional authors in forming the basic structure of classical texts, as this element is able to provide a positive impact in terms of the loyalty of the people and the credibility of the king in administrative affairs. The greatness of traditional authors in embodying the message to the masses through a mixture of extraordinary events has a big implication to the masses and evokes feelings of awe and amazement. One of these emotions is astonishment, which leads to feelings of awe and amazement. The question that this study seeks to unravel is, are the events that exist in the text of Hikayat Marakarmah able to evoke feelings of astonishment and awe in the masses? The objective of this study is to examine the relationship between the feeling of astonishment and the aspect of spiritual relief that will be unraveled based on the selected text. The method applied in this study is qualitative in nature, under a descriptive analysis that is focused on text. The data description and information obtained from this textual analysis will be divided into two, a structural analysis, which looks at the structure of the sentence and the language style that are able to evoke feelings of astonishment and amazement, as well as a theoretical analysis that examines these emotional aspects through phemenology, therefore linking feelings of astonishment and the impact of amazement with aspects of spiritual relief. The results of these analyses have found that there are indeed several events in Hikayat Marakarmah that have evoked emotions of astonishment and amazement, and they are able to provide a sense of spiritual relief to
\end{abstract}


the masses. In conclusion, the amazement of the masses in response to many of the events in Hikayat Marakarmah promotes a sense of relief, therefore proving the greatness of traditional authors in blending aspects of aesthetics and the hidden message that they wish to convey.

Key words: Magical, Emotions, Astonishment, Amazement, Aesthetic and Spiritual Relief

\section{PENGENALAN}

Kamus Dewan Edisi Keempat (2015) memberi takrifan magis sebagai sesuatu unsur luar biasa yang mempunyai keupayaan tersembunyi atau ghaib manakala istilah hairan ialah suatu rasa yang pelik, ganjil dan takjub ketika melihat atau mendengar sesuatu. Emosi hairan ini disertai dengan tindakan refleks tercengang-cengang beserta kagum terhadap sesuatu peristiwa yang berkaitan. Emosi hairan ini lazimnya hadir ketika khalayak berhadapan dengan peristiwa yang di luar jangka yang terdapat di dalam teks-teks klasik bercorak hikayat. Emosi hairan yang memberikan kesan rasa takjub ini meninggalkan suatu pengalaman yang sukar dilupakan kepada khalayak. Hal ini adalah kerana selain merasa takjub dengan peristiwa luar biasa yang terdapat di dalam teks, khalayak juga merasa kagum terhadap keupayaan pengarang mewujudkan sesuatu peristiwa di luar duga. Magis ini merupakan suatu elemen seni kepengarangan yang di adun di dalam teks hikayat bagi meningkatkan mutu estetikanya. Muhammad Haji Salleh dalam Puitika Sastera Melayu: Satu Pertimbangan (1989) menjelaskan terdapat enam unsur yang mendasari keindahan hikayat dunia Melayu. Enam unsur tersebut ialah menceritakan kehidupan, mengajar dan membimbing, dunia pengalaman yang dirundung kesusahan, kesedihan dan kesengsaraan, keaslian, cerita yang episodik, unsur dramatik dan perasaan takjub dan hairan kepada dunia magis.

Hikayat dunia alam Melayu yang mempunyai keenam-enam ciri ini menepati konsep estetikanya yang tersendiri namun lazimnya sebuah karya hikayat mempunyai dua atau tiga ciri yang dinyatakan. Perasaan takjub atau hairan kepada perkara magis merupakan elemen penting yang mewarnai karya hikayat. Muhammad Haji Salleh turut menjelaskan aspek kesaktian dan keajaiban menampilkan citra kekaguman dalam diri manusia. Makna kagum ialah sangat tertarik melihat atau mendengar sesuatu yang luar biasa (Kamus Dewan Edisi Keempat, 2015). Kagum ialah situasi yang mempunyai hubungkait dengan sesuatu yang luar biasa dan keluarbiasaan itu mempunyai hubungan dengan watakwatak tertentu (Sohaimi Abd Aziz, 1998). Dua aspek ini iaitu keajaiban dan kesaktian menawarkan kepada masyarakat tentang suatu dunia yang mengandungi pelbagai tanda yang mendeskripsikan kebaikan, kehebatan dan kebesaran watak-watak yang menjadi sanjungan mereka. Pemerian watak dan kuasa yang dimiliki oleh watak yang dicipta pengarang dianggap supreme iaitu tidak ada tolok bandingnya. Kuasa magis tradisional ini mengubah latar cerita seakan syurga (Muhammad Haji Salleh, 2000). Latar cerita yang seakan syurga inilah yang menimbulkan tarikan kepada khalayak sekali gus mendatangkan rasa takjub. Tambahan pula, elemen magis yang di tampilkan di dalam karya yang disertai dengan perkara-perkara keajaiban dan kesaktian menepati konsep estetika karya. Kesan rasa takjub yang terbit dalam diri khalayak ini dikategorikan sebagai suatu tidak balas keindahan kerana terhasil daripada pengalaman estetik yang diperoleh ketika khalayak menikmati karya sekali gus mendatangkan kepuasan terhadap jiwa khalayak.

Hikayat Marakarmah mempunyai dua nama. Satu nama Hindu iaitu Hikayat Marakarmah dan satu lagi nama Islam Hikayat Si Miskin. Windstedt (2016) dalam bab pengantar Hikayat Si Miskin menjelaskan bahawa sastera yang mempunyai dua nama seperti ini terhasil daripada zaman peralihan iaitu antara zaman Hindu ke zaman Islam. Hikayat Marakarmah ialah salah satu karya yang membuktikan wujudnya pertembungan dua kebudayaan besar yang pernah menapak di Alam Melayu. Kedua-dua kebudayaan ini meninggalkan pengaruh yang besar kepada masyarakat Melayu khususnya daripada aspek adat-resam, kepercayaan, tradisi dan pemikiran masyarakat Melayu serantau. Hikayat Marakarmah memerihalkan penceritaan tentang seorang anak raja yang bernama Marakarmah yang membawa maksud anak dalam kesukaran. Permulaan hikayat ini menceritakan tentang kisah hidup Si Miskin iaitu ayahanda kepada Marakarmah yang miskin dan melarat di hutan. Si Miskin hidup dalam 
keadaan susah kerana sumpah Betara Indera. Si Miskin dikurniakan anak lelaki yang bernama Marakarmah.

Setelah kelahiran Marakarmah ini, kehidupan Si Miskin mula berubah apabila beliau terjumpa dengan tajau berisi emas yang sangat banyak di hutan lalu menjadi raja dengan gelaran Maharaja Indera Angkasa dengan isterinya yang bernama Tuan Puteri Ratna Dewi dan negerinya bernama Puspasari. Si Miskin atau Maharaja Indera Angkasa kemudiannya dikurniakan seorang puteri yang bernama Tuan Puteri Nila Kesuma. Marakarmah dan adiknya Tuan Puteri Nila Kesuma kemudiannya dibuang ke hutan kerana fitnah ahli nujum yang mempunyai niat jahat untuk menjatuhkan negeri. Maharaja Indera Angkasa mempercayai kata-kata ahli nujum bahawa kedua-dua anakanda baginda ini akan mendatangkan malapetaka kepada negeri Puspasari. Baginda kemudiannya menghalau anak-anaknya ke dalam hutan. Setelah kedua-dua anaknya dihalau dan dibuang ke dalam hutan keseluruhan negeri Puspasari terbakar dan ramai rakyat keluar meninggalkan negeri Puspasari untuk menyelamatkan diri masing-masing.

Tuan Puteri Nila Kesuma terpisah dengan abangnya ketika berada di hutan diambil serta dijaga oleh sepasang suami isteri iaitu Raja Puspa Indera dan permaisurinya iaitu Tuan Puteri Mandu Ratna di sebuah negeri bernama Pelinggam Cahaya. Baginda berdua menamakan Tuan Puteri Nila Kesuma dengan nama Tuan Puteri Mayang Mengurai dan mengahwinkan puteri ini dengan anakanda mereka yang bernama Raja Mengindera Sari. Raja Marakarmah pula telah menyelamatkan Tuan Puteri Cahaya Khairani iaitu seorang puteri anak kepada raja jin yang bernama Raja Malai Kisna daripada Negeri Mercu Indera dan mengahwini puteri tersebut. Raja Marakarmah ditolak oleh seorang nakhoda yang dengki khianat dan berkehendakkan Tuan Puteri Cahaya Khairani lalu diselamatkan oleh ikan nun. Tuan Puteri Cahaya Khairani dibawa oleh nakhoda tersebut ke sebuah negeri bernama Pelinggam Cahaya dan di negeri ini Marakarmah ditemukan kembali dengan adindanya yang hilang di hutan iaitu Tuan Puteri Nila Kesuma.

Adinda kepada Tuan Puteri Cahaya Khairani bernama Raja Bujangga Indera merupakan sahabat kepada Marakarmah. Maharaja Indera Dewa di Negeri Anta Beranta mempunyai seorang puteri bernama Tuan Puteri Nila Cahaya. Tuan Puteri Nila Cahaya ini dikahwinkan dengan Raja Bujangga Indera dan di rajakan di negeri Anta Beranta. Raja Mengindera Sari dan Tuan Puteri Nila Kesuma di rajakan di negeri Pelinggam Cahaya manakala Marakarmah dan Tuan Puteri Cahaya Khairano menjadi raja di Mercu Indera. Negeri Puspasari yang terbakar dahulu kembali seperti asal apabila Marakarmah dan adinda baginda Tuan Puteri Nila Kesuma memaafkan kesalahan kedua orang tua mereka yang termakan fitnah ahli nujum. Terdapat banyak peristiwa yang terdapat di dalam Hikayat Marakarmah yang menerbitkan emosi hairan khalayak. Bauran emosi khalayak merupakan cabang kepada falsafah estetika yang terdapat di dalam teori rasa fenomenologi. Hal ini demikian kerana, emosi khalayak yang wujud merupakan tindakbalas kepada keupayaan serta kebijaksanaan pengarang membawa kronologi sesuatu naratif penceritaan dengan sempurna.

\section{TINJAUAN LITERATUR}

Noriah Taslim (2006, ms. 114-115) di dalam artikel Mantera dan Kuasa: Manusia dan Dunia Sihir menjelaskan istilah magis dan perkaitan dengan manusia di dalam hikayat Melayu. Menurut beliau, magis diperlukan hadir semasa manusia primitif berdepan dengan situasi tertentu seperti ancaman, kepayahan atau tekanan emosi yang perit, yang dalam keupayaannya yang normal tidak dapat di atasi atau dileraikan.

Emosi ialah perasaan jiwa yang kuat (Kamus Dewan Edisi Keempat, 2015). Emosi hairan pula ialah emosi dominan yang terbina daripada suatu keadaan yang mengejutkan. Antara keadaan yang boleh mewujudkan emosi ini ialah elemen yang tidak disangka-sangka, elemen luar biasa dan pemakaian objek yang berlebih-lebihan. (Nordiana Hamzah, 2014). Hikayat Melayu yang lahir pada zaman periodisasi Hindu-Islam banyak memerihalkan aspek ini. Salah satu daripadanya ialah Hikayat Marakarmah yang digunakan di dalam kajian ini. Emosi hairan yang mampu menimbulkan rasa kagum 
khalayak merupakan wadah utama dalam merasang keseronokan dan memenuhi objektif karya yang pada ketika itu yang hanya bertujuan untuk memberi hiburan.

Abdul Halim Ali (2010) dalam tesis Ijazah Doktor Falsafah yang berjudul Konsep Estetika Bersepadu: Terapan dan Analisis Terhadap Karya-Karya Puisi Ahmad Kamal Abdullah menerangkan perkataan estetik berasal daripada perkataan aesthesis yang membawa makna kepekaan bagi menjelaskan perkaraperkara yang berkaitan dengan perihal indah dan keindahan. Istilah estetik sinonim dengan istilah indah namun bagi memahami konsep keindahan dalam seni sastera tidak terbatas kepada aspek yang dilihat indah sebagai indah. Unsur-unsur lain seperti lucu, sedih, derita, kecewa juga dikira sebagai unsur yang boleh meransang keseronokkan. Karya seni yang kelihatan hodoh dan ngeri sekiranya berupaya menimbulkan rasa takjub, hairan dan seronok dalam jiwa boleh digolongkan sebagai indah.

Pengalaman estetik di dalam karya hanya boleh hadir apabila berlaku perhubungan antara karya, pengarang dan pembaca (Nordiana Hamzah, 2014). Pembaca, penulis dan karya berada di dalam kesatuan universal. Karya menjadi perantara pengarang dan pembaca. Kegagalan di suatu pihak akan mengagalkan pengahyatan dan keberkesanan pengalaman estetik. Pengalaman estetik bergantung kepada emosi khalayak. Menurut Hairul Anuar Harun (2017) menjelaskan pendekatan estetika atau keindahan ini pada hakikatnya, apabila diaplikasikan, cenderung menjelaskan nilai-nilai keindahan yang terungkap di dalam sebuah karya dengan pemberatan kepada perkara-perkara seperti kesan keindahan emosi, pengalaman, imaginasi dan wawasan serta memahami keindahan gaya bahasa pengarang sebagai keistimewaan dalam usaha mengolah karya.

Muharroni (2016) pula dalam tesis Ijazah Sarjana yang berjudul Nilai Estetik Pantun dan Tradisi Nikah Kahwin Masyarakat Melayu Tanjung Pinang Riau Inonesia turut mengulas tentang pendekatan estetika yang dilihat sebagai suatu nilai yang tidak boleh dipisahkan daripada sebuah karya sastera. Karya sastera adalah pancaran akal budi dan gugusan idea seorang pengkarya yang disampaikan melalui daya kepengarangannya. Oleh itu, hasil karya bukan setakat pengubat jiwa malahan secara tidak lansung, pengarang turut menjadi guru dalam hal-hal berkaitan manusia dan kemanusiaan.

\section{METODOLOGI KAJIAN}

Kajian ini mengaplikasikan kaedah kualitatif di bawah analisis deskriptif. Analisis deskriptif ini melibatkan huraian terperinci mengenai teks kajian iaitu Hikayat Marakarmah, peristiwa magis yang terdapat di dalam teks dan kaitan teori rasa fenomenologi serta aspek kelegaan jiwa (katarsis). Data daripada kajian ini dikumpulkan menerusi kaedah kepustakaan, kaedah laman sesawang menerusi carian google scholar serta beberapa web jurnal lain seperti Pendeta dan Jurnal Rumpun serta kaedah analisis tekstual yang melibatkan teks kajian. Kaedah analisis tekstual melihat kepada dua aspek iaitu struktural dan teoritikal. Aspek struktural melihat kepada struktur ayat yang melibatkan pemilihan gaya bahasa yang memaparkan sesuatu yang disebut sebagai magis dan aspek teoritikal pula melihat emosi hairan dalam teori rasa fenomenologi serta mengaitkan dengan kesan kelegaan jiwa (katarsis).

Teori rasa fenomenologi ialah gabungan dua teori iaitu teori rasa di India dan teori estetik fenomenologi. Teori rasa ialah teori estetik yang berasal dari India dan kewujudannya adalah lebih awal daripada teori estetik di Barat. Istilah rasa adalah sangat berkait dengan emosi atau perasaan. Aspek emosi adalah salah satu aspek yang penting dalam membicarakan keindahan seni dalam teori rasa. Teori rasa dikemukakan oleh Bharata Muni pada abad ke-5 hingga ke-6 Masihi di dalam sebuah karya yang berjudul Natyasastera. Kemudian, teori ini telah dimantapkan oleh Abhinavagupta pada abad ke-10 Masihi. Teori estetik fenomenologi pula ialah teori estetik yang bersifat psikologikal formalistik yang diasaskan oleh Roman Ingarden, seorang fenomenologis Poland. Teori ini bersifat psikologikal formalistik kerana membincangkan bentuk atau struktur karya serta peranan pembaca terhadap struktur berkenaan.

Teori rasa fenomenologi menerangkan konsep emosi yang diterima diambil daripada teori rasa manakala kesan emosi dikaitkan dengan pengalaman keindahan yang terbit didapati daripada teori 
estetik fenomenologi. Konsep hakikat jiwa kekal diganti dengan konsep emosi utama. Apabila emosi utama ini diransang menerusi objek estetik (karya sastera) maka kehadirannya akan dapat dirasai dan dinikmati dalam minda pembaca. Emosi utama ini hadir dalam kesedaran estetik dan emosi utama yang telah ditransformasikan pula dikenali sebagai emosi estetik. Teori rasa fenomenologi menjelaskan proses transformasi emosi dan karya berlaku ketika seseorang itu mengecapi pengalaman estetik.

Teori rasa fenomenologi memberatkan emosi sebagai salah satu aspek penting dalam membicarakan karya seni (Sohaimi Abd Aziz, 2005). Emosi-emosi yang terdapat di dalam teori ini mempunyai lapan jenis dan terbahagi kepada dua kategori iaitu emosi tetap dan emosi peransang. Lapan emosi tetap bertindak balas dengan lapan emosi perangsang bergantung kepada korelatif objektif bagi peristiwa tertentu (Sohaimi Abd Aziz, 2014). Lapan emosi tetap dan emosi perangsang yang dimaksudkan ialah kasih (berahi), riang (lucu), sedih (duka), marah (berang), bertenaga (wira), takut (dahsyat), jijik (benci) dan hairan (kagum). Kajian ini akan melihat emosi tetap hairan dan emosi perangsang kagum yang akan dianalisis berdasarkan Hikayat Marakarmah ini.

\section{ANALISIS DAN PERBINCANGAN}

Berdasarkan analisis daripada dapatan kajian mendapati terdapat 12 peristiwa yang terdapat di dalam teks Hikayat Marakarmah yang berupaya memberikan kesan emosi hairan kepada khalayak. Kesan emosi hairan yang diperoleh ini diukur bersandarkan struktur ayat dan gaya bahasa yang digunakan oleh pengarang di dalam teks. Kehebatan pengarang tradisi mengadun kedua-dua aspek ini iaitu struktur ayat dan teknik pemerian gaya bahasa yang sesuai menimbulkan sesuatu yang dikatakan 'indah' dan keindahan ini menangkap rasa lega di dalam jiwa khalayak. Kelegaan jiwa kepada khalayak ini hadir apabila khalayak menikmati karya sebagai 'objek estetik' dan proses pembacaan dan transformasi emosi yang berlaku sebagai 'pengalaman estetik'. Pengalaman estetik yang diperoleh dalam teks memberikan kesan lega kepada jiwa khalayak. Rajah 1 merupakan analisis hubung kait peristiwa magis dan kesan emosi takjub yang terdapat di dalam Hikayat Marakarmah.

\section{Petikan Peristiwa Magis (HM- Hikayat Marakarmah)}

\footnotetext{
Peristiwa 1

Setelah sudah ia mandi, maka diambilnyalah anaknya itu seraya ia berkata, "Jikalau sungguhsungguh anak dewa-dewa hendak menerangkan muka ayahanda ini, jadilah negeri di dalam hutan ini sebuah lengkaplah dengan kota parit dan istananya serta dengan menteri, hulubalang, rakyat sekalian dan segala raja-raja di bawah baginda betapa adat segala raja-raja yang besarbesar". Maka dengan takdir Allah SWT menunjukkan kudrat dan iradatnya atas hambanya, maka jadilah negeri dengan selengkapnya alat kerajaan itu. Maka, Si Miskin bersalin nama Maharaja Indera Angkasa dan isterinya dinamai Tuan Puteri Ratna Dewi dan negerinya dinamai Puspasari.
}

Huraian

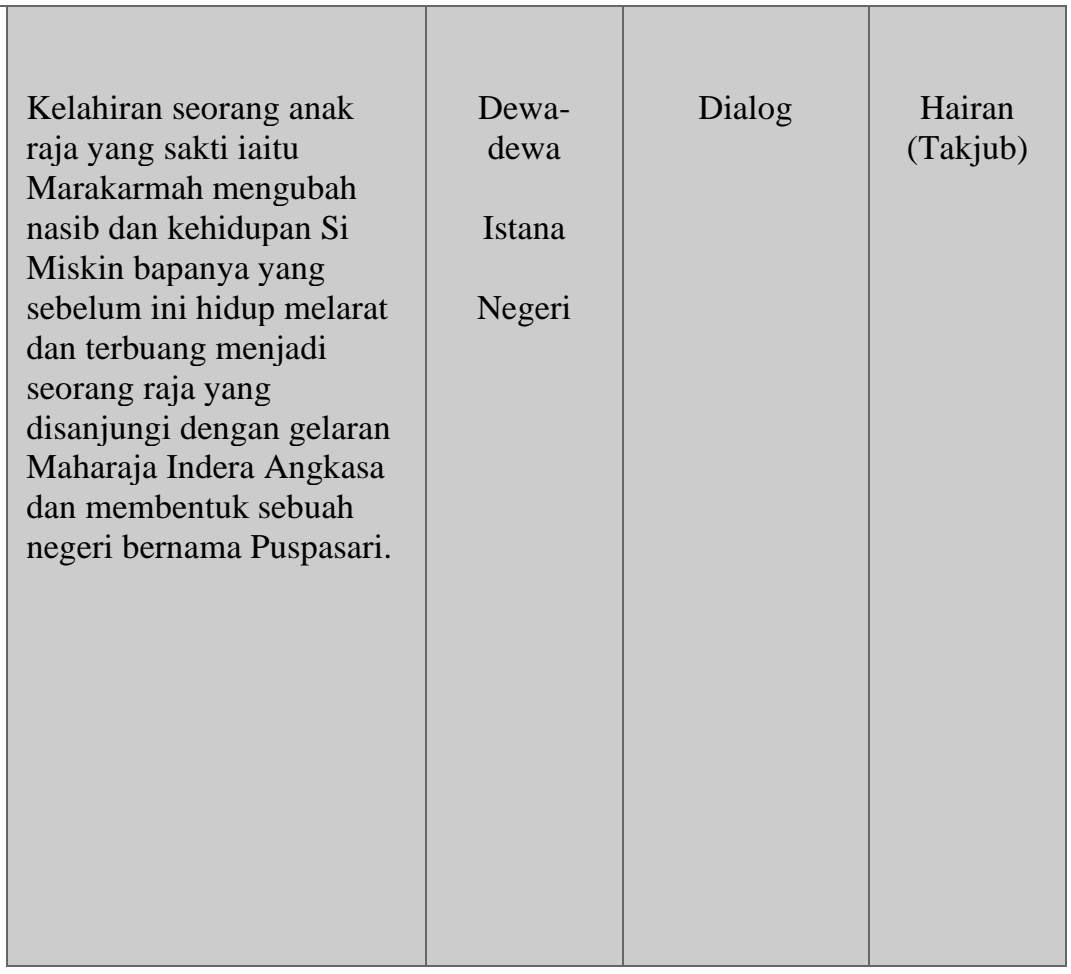

\section{Struktur Gaya Bahasa Emosi Ayat}


(HM, 2016: m.s 7)

\section{Peristiwa 2}

Demikianlah, setelah sampailah tiga hari Marakarmah itu pergi, maka negeri Puspasari pun terbakarlah, suatu pun tiada yang tinggal, habislah di makan oleh api sekalian.

(HM, 2016: m.s 15)

\section{$\underline{\text { Peristiwa } 3}$}

Setelah sudah dibuangkan oleh orang dusun itu ke dalam laut, maka hanyutlah di bawa oleh arus; terdamparlah ke tepi pantai dengan ikatnya juga. Sebermula, adapun pantai itu pangkalan raksasa. Adapun raksasa itu ada melarikan anak raja jin seorang perempuan, terlalu baik parasnya, bernama Tuan Puteri Cahaya Khairani.

(HM, 2016: m.s 29)

\section{Peristiwa 4}

Maka, ikan nun itu pun menundukkan kepalanya seperti

laku orang rupanya, seraya katanya, "Ya Tuanku Maharaja

Marakarmah, busuklah perut patik dan matilah patik memakan

Tuanku. Jikalau tuanku hendak pergi barang ke mana marilah patik hantarkan".

(HM, 2016: m.s 41)

Marakarmah yang terpisah dengan adiknya di hutan kerana mencari arang di dusun dibuang orang ke dalam laut dan terdampar di tempat Puteri Cahaya Khairani disembunyikan oleh raksasa. Maharaja Marakarmah berusaha memberikan pertolongan dengan cara menyelamatkan Puteri Cahaya Khairani daripada menjadi tawanan dan makanan kepada raksasa.

\section{Ikan Nun yang}

\section{menyelamatkan}

Marakarmah yang terjatuh ke dalam laut kerana di tolak oleh nakhoda yang dengki khianat padanya kerana berkehendakkan Puteri Cahaya Khairani. 


\section{$\underline{\text { Peristiwa } 5}$}

Setelah itu, maka ikan nun itu pun terdampar ke darat kepada pangkalan Nenek Kebayan itu. Maka, Nenek Kebayan itu pun bangunlah daripada tidurnya pagi-pagi hari lalu ia pergi kepada pangkalannya hendak membasuh muka. Maka, dilihatnya ada seekor ikan nun terlalu amat besar terdampar di pasir betul di pangkalan Nenek

Kebayan. Seketika itu, maka datanglah seekor burung rajawali melayang-layang hampir Nenek Kebayan itu seraya katanya, "Hai Nenek Kebayan, ambil daun padi, toreh perut ikan nun itu. Ada seorang anak raja di dalam perutnya”.

(HM, 2016: m.s 42)

\section{Peristiwa 6}

Maka sahut Nenek Kebayan, "Bukannya demikian, kerana nenek sudah berjanji dengan Tuan Puteri itu hendak mengajar menggubah bunga, sekarang ini apalah akal nenek kerana tiada tahu”. Setelah di dengar oleh Marakarmah kata neneknya, maka ia pun tertawa-tawa gelak seraya katanya, "Diamlah nenek, jangan menangis, biarlah aku suruhkan lalat hijau mengikut nenek, barang dimana ia hinggap di sanalah nenek turut masukkan bunga itu”.

(HM, 2016: m.s 45)

\section{$\underline{\text { Peristiwa } 7}$}

Arakian, adapun akan Marakarmah itu, sepeninggal Nenek Kebayan itu sudah pergi dipanggi baginda itu, maka ia pun mencita kemala hikmat yang diberi oleh bota di tengah padang Sular Mandi itu. Maka, turunlah kuda semberani dengan selengkap pakaian yang indah-indah serta dengan penggawa orang mudamuda empat puluh orang. Maka,
Nenek Kebayan yang membantu mengeluarkan Maharaja Marakarmah daripada perut ikan Nun hanya dengan menggunakan daun padi.
Peristiwa Nenek Kebayan yang menggubah bunga mengikut pergerakan Lalat Hijau dan kehebatan Marakarmah membuatkan lalat hijau menurut perintahnya membantu membuat gubahan buat sang puteri.
Peristiwa Marakarmah membuat persiapan berjumpa semula dengan adindanya dan isterinya yang terpisah di negeri Pelinggam Cahaya.

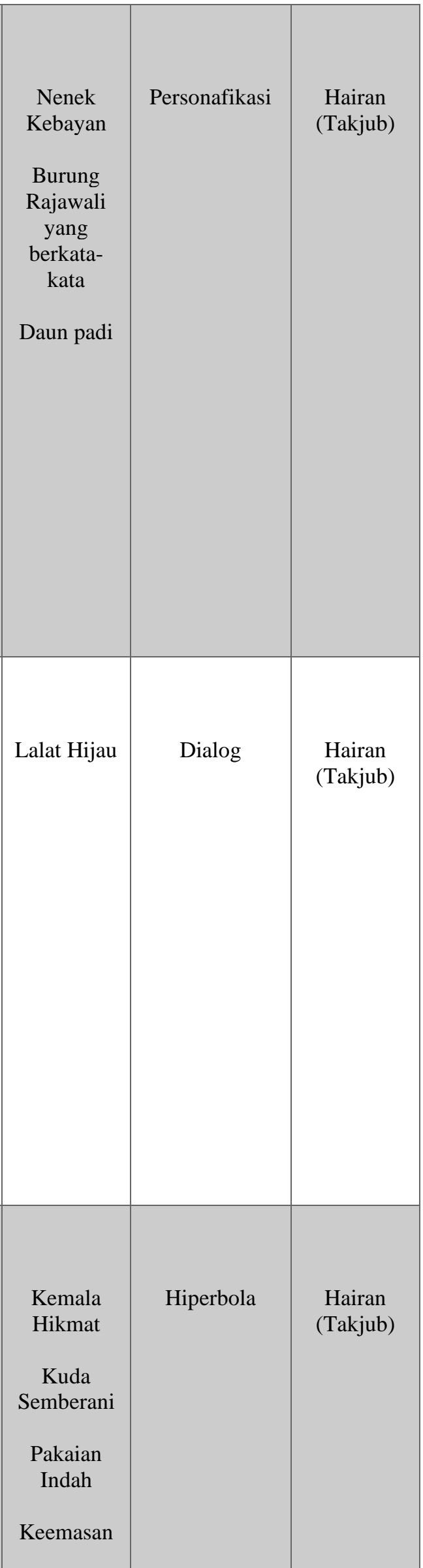


Marakarmah pun memakailah dengan selengkap pakaian yang keemasan itu.

(HM, 2016: m.s 51)

\section{Peristiwa 8}

Setelah sudah, maka Maharaja Marakarmah itu pun keluar mencita negerinya. Maka, dengan seketika itu juga Negeri

Puspasari itu pun kembalilah seperti sediakala itu. Sekalian raja-raja dan menteri,

hulubalang, rakyat sekaliannya lengkaplah dengan kota paritnya dan istananya lebih besar pula daripada dahulunya itu serta dengan mahligainya tujuh belas pangkat itu dan kota paritnya tujuh lapis. Maka, segala bunyibunyian pun di palu oranglah alamat kedatangan suka itu. Maka, baginda laki isteri itu pun terlalu hairan melihat kesaktian anakanda baginda itu.

(HM, 2016: m.s 62)

\section{Peristiwa 9}

Alkisah, maka tersebutlah perkataan ceteranya Maharaja

Indera Dewa di negeri Anta

Beranta nama negerinya. Setelah baginda mendengar khabar warta

orang mengatakan Maharaja

Marakarmah sudah datang mendapatkan ayahnya ke negeri Puspasari dari Negeri Pelinggam

Cahaya itu dan ia beristerikan anak raja jin yang bernama

Maharaja Malai Kisna terlalu besar kerajaan baginda itu.

Maka, baginda itu adalah

beranak dua orang, yang tua perempuan bernama Tuan Puteri

Cahaya Khairani ialah yang dilarikan oleh raksasa itu dan yang muda itu laki-laki bernama Raja Bujangga Indera, ialah yang bersahabat dengan Maharaja

Marakarmah, tatkala bermain lancang dengan segala anak rajaraja jin di tasik Indera Semendera itu. (HM, 2016: m.s 73)

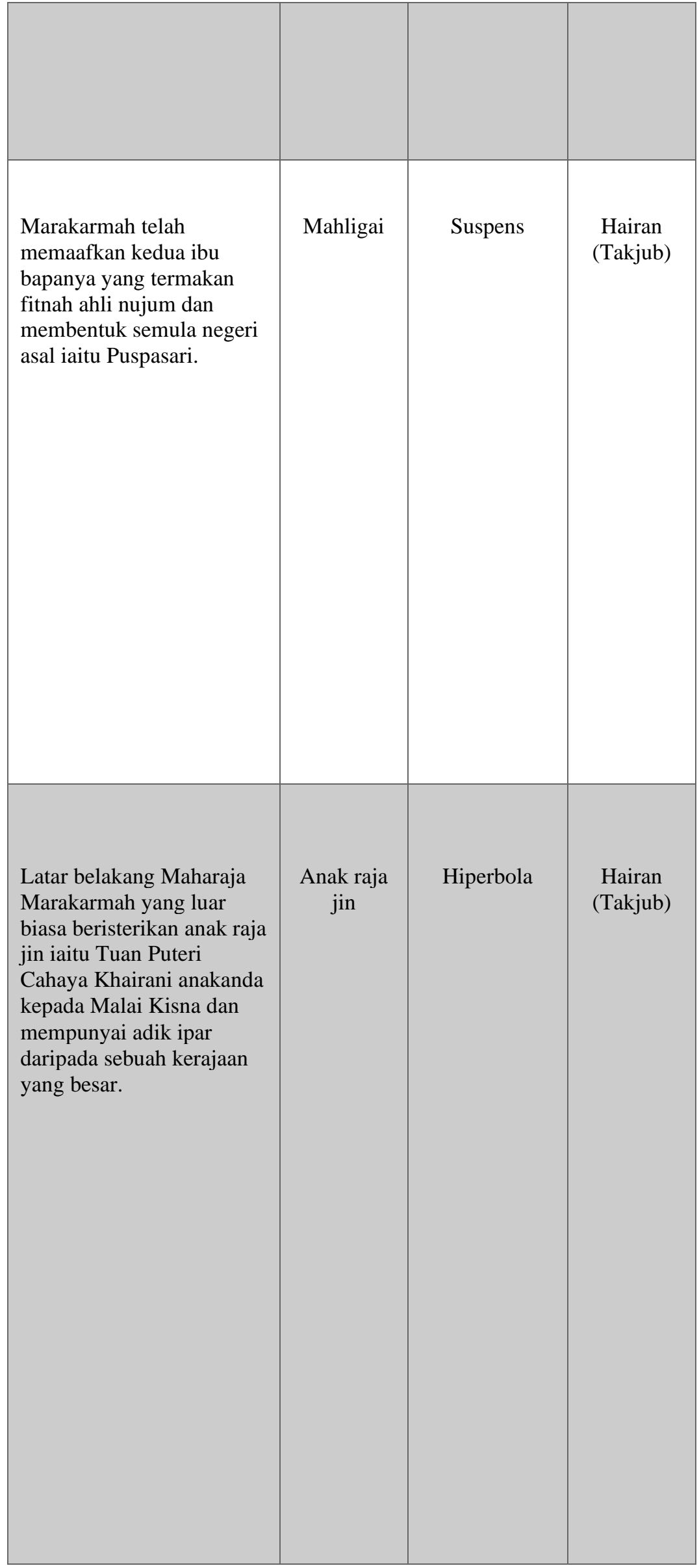




\section{Peristiwa 10}

Setelah sudah berhormathormatan lalu dibawanya berjalan bersama-sama sambil melihat ke kiri dan ke kanan, ke hadapan dan ke belakang. Maka dilihatnya tentera terlalu banyak seperti laut rupanya. Maka, Maharaja Marakarmah pun teringat akan geliga yang di beri oleh Maharaja Dewanggara yang duduk bertapa di gunung berjentera itu, lalu diambilnya, diunjukannyalah geliga itu di tengah padang seraya mencita nama Maharaja Dewanggara. Maka, dengan seketika itu juga jadilah sebuah negeri terlalu besar, lengkap dengan kota paritnya dan istananya. Maka, segala raja-raja dan menteri dan baginda kedua itu pun terlalu hairan melihat kesaktian Maharaja Marakarmah itu.

(HM, 2016: m.s 87)

\section{Peristiwa 11}

Maka, Maharaja Marakarmah itu pun segera melompat lalu memanah ke udara. Maka, turunlah hujan terlalu lebat. Maka, api itu pun padamlah.

Setelah dilihat oleh Maharaja Indera Dewa saktinya tewas oleh Maharaja Marakarmah, maka ia terlalu marah lalu ia memanah ke maghrib, maka datanglah ular naga beribu-ribu mengusir

Maharaja Marakarmah. Maka, segeralah dipanah oleh Maharaja Marakarmah, seraya memanah ke masyrik. Maka, datanglah raksasa beribu-ribu memakan ular naga itu. Maka, segala ular naga itu pun habislah seekor tiada tinggal.

(HM, 2016: m.s 92)

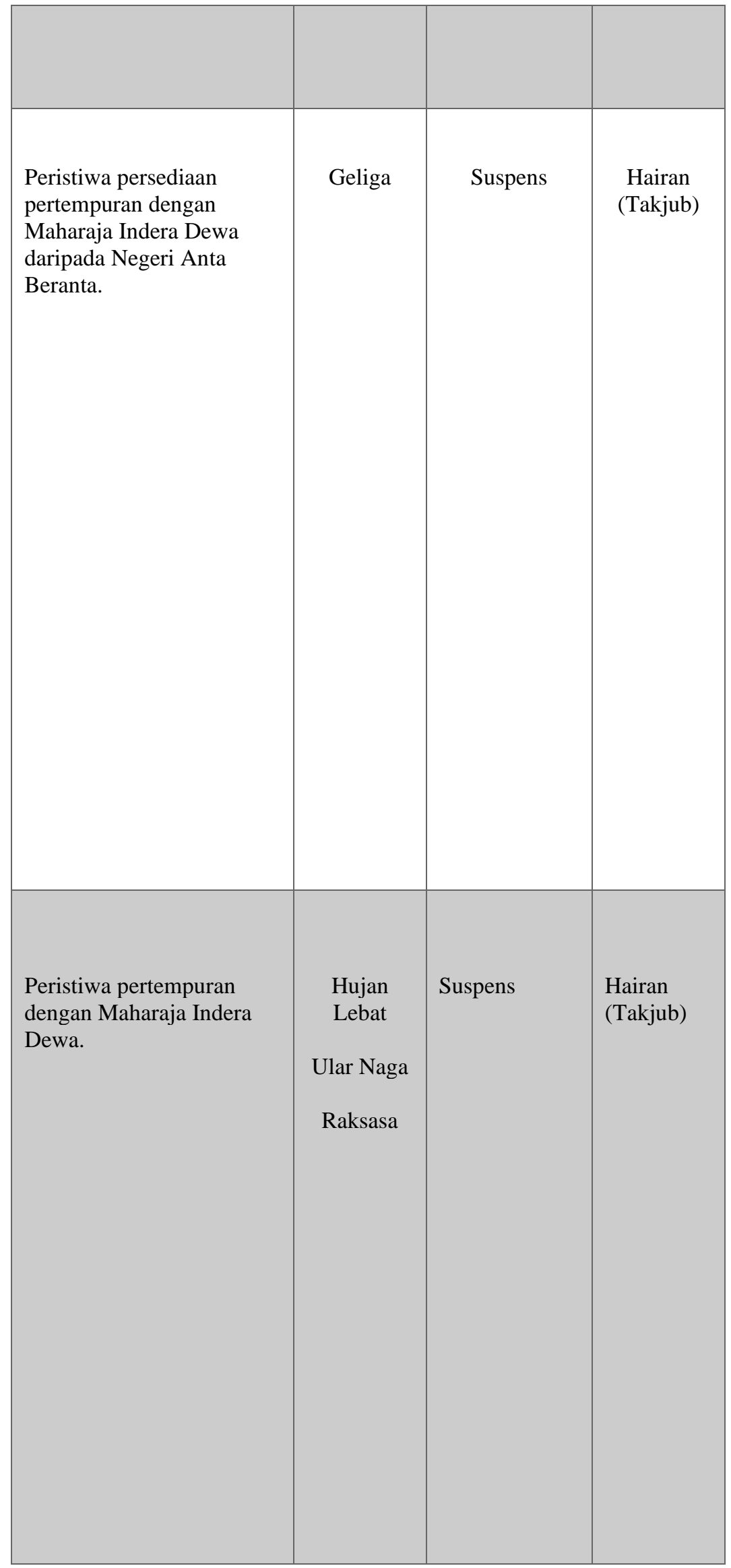




\section{Peristiwa 12}

Maka, Maharaja Malai Kisna Indera pun memanah ke udara. Maka, turunlah hujan bunga rampai. Setelah dilihat oleh Maharaja Mengindera Dewa, maka ia pun memanah ke udara, maka turunlah hujan air mawar membasahkan pakaian segala anak raja yang membawa

kebesaran itu. Maka, Raja Mengerana Lela pun segeralah memanah ke udara, turunlah angin lemah lembut yang mengeringkan pakaian segala anak raja-raja itu. Maka, Dikar Agas Peri pun segeralah memanah ke udara, turunlah hujan permata ratna mutu manikam, maka ramailah orang negeri Mercu Indera itu memungut permata itu. Maka, baginda ketiga itu pun hairanlah melihat kesaktian segala anak raja-raja itu, maka beraraklah sampai lalu masuk ke istana.

(HM, 2016: m.s 106)

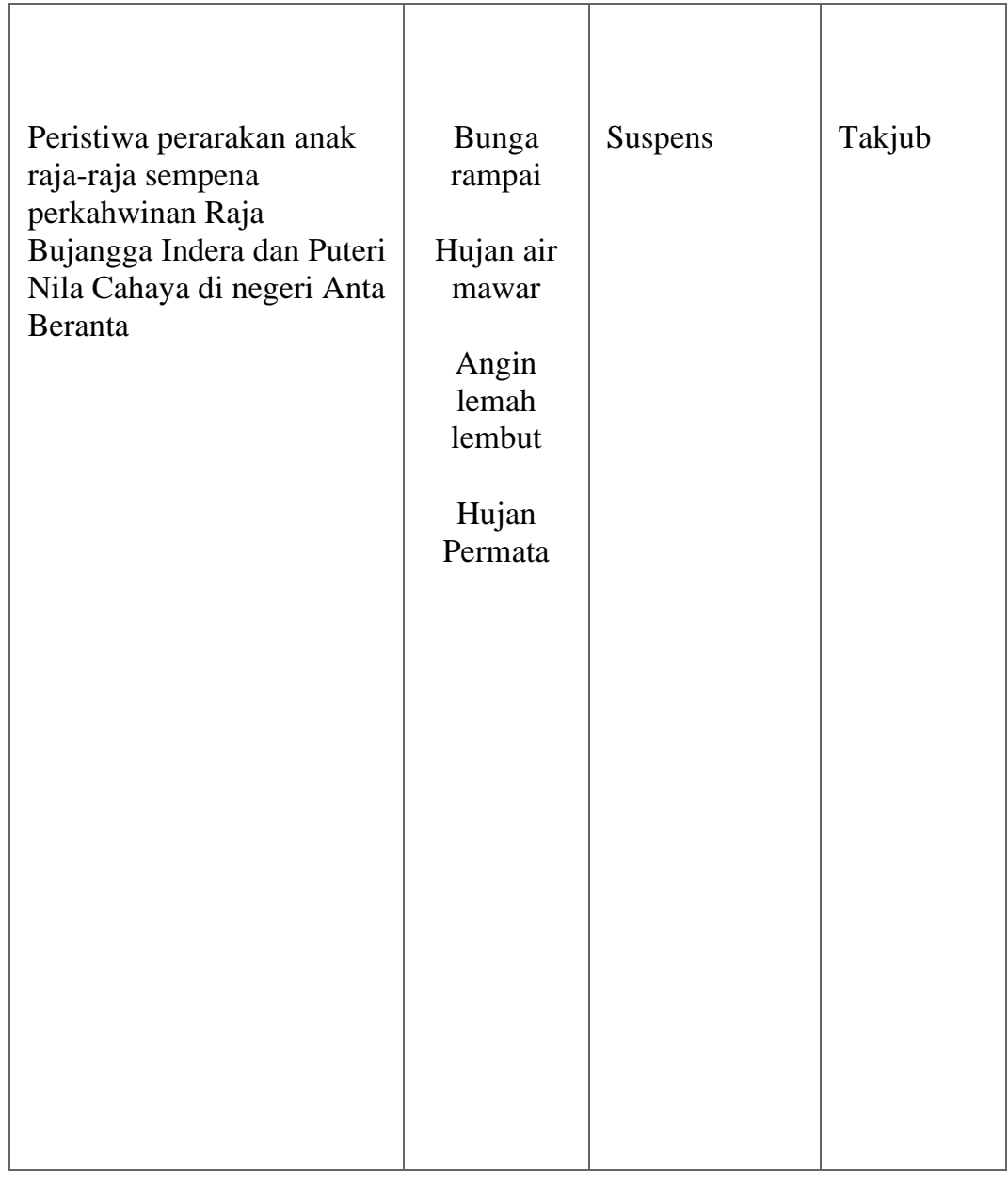

Rajah 1. Hubung kait Peristiwa Magis yang terdapat di dalam Hikayat Marakarmah dan Kesan Emosi Takjub dalam Teori Rasa Fenomenologi.

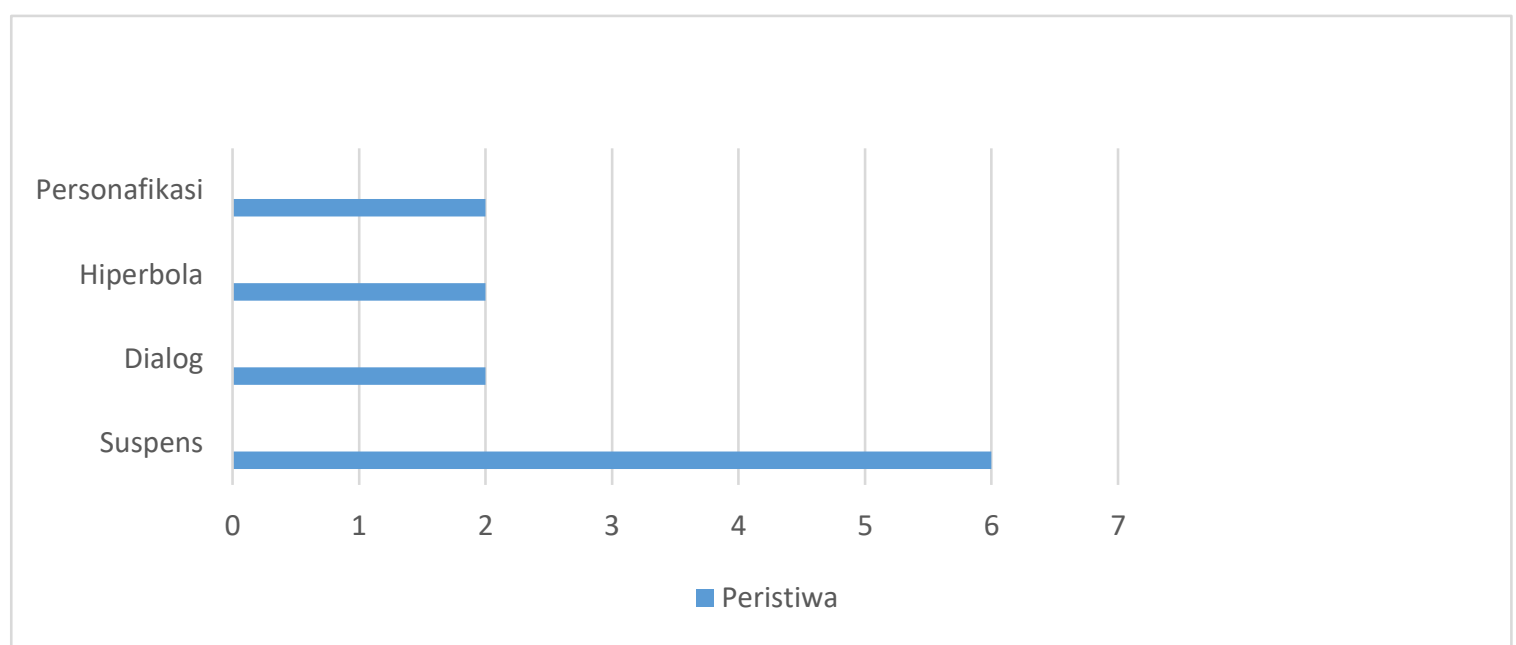

Rajah 2. Gaya bahasa yang digunakan oleh pengarang dalam menimbulkan rasa hairan di dalam Hikayat Marakarmah.

Rajah 1 memerihalkan dengan jelas pemilihan diksi yang sesuai dalam sesuatu peristiwa menyerlahkan kesan emosi hairan yang wujud pada khalayak. Sebagai contoh, pemilihan kata dewa, istana, anak raja jin, geliga, ular naga, raksasa, nenek kebayan, burung rajawali yang berkata-kata, ikan nun, daun padi dan kuda semberani memerlukan imaginasi khalayak untuk membayang kerana diksi yang dipilih tidak bersifat nyata. Keindahan di dalam membayang 
sesuatu yang bersifat subjektif ini menimbulkan kesan rasa takjub. Hal ini yang dikaitkan dengan kebijaksanaan pengarang tradisi membawa mesej hiburan kepada khalayak menerusi genre hikayat. Apabila keindahan tadi yang mendatangkan rasa takjub diimbangi dengan keseimbangan estetik maka hadir sesuatu yang dikatakan 'lega' di dalam jiwa khalayak. Oleh itu, dengan ini jelas emosi hairan yang terbit di dalam menikmati peristiwa yang terdapat di dalam teks meruntun jiwa khalayak apabila bauran magis yang hadir bersama pengaruh ideologi Hindu di seimbangkan dengan unsur Islam mendatangkan kesan kelegaan jiwa kepada khalayak.

Sehubungan dengan itu, berdasarkan Rajah 2 hasil analisis mendapati daripada 12 peristiwa yang melibatkan emosi hairan di dalam Hikayat Marakarmah ini enam peristiwa melibatkan gaya bahasa suspens iaitu sesuatu yang di luar jangkauan khalayak, dua peristiwa melibatkan gaya bahasa dialog, dua peristiwa melibatkan gaya bahasa personafikasi iaitu sesuatu benda yang diberikan watak perorangan dan dua peristiwa yang melibatkan gaya bahasa hiperbola iaitu perbandingan yang melebih-lebih. Gaya bahasa suspens mendominasi sebanyak enam peristiwa berbanding gaya bahasa lain. Sebagai rumusan, hasil dapatan ini membuktikan teknik gaya bahasa suspens yang banyak digunakan oleh pengarang tradisi berkaitan dengan hal ehwal magis di dalam teks hikayat ini berupaya menimbulkan keindahan sekaligus kesan kelegaan jiwa kepada khalayak. Pengarang membuatkan khalayak tertanya-tanya tentang peristiwa selanjutnya membuktikan karya sastera genre hikayat ini bersifat indah dan menerbitkan rasa puas khalayak setelah mengetahui peristiwa yang terjadi lanjutan daripada peristiwa sebelumnya. Hal ini sebenarnya yang dikatakan kepuasan dan kelegaan kepada jiwa khalayak.

\section{KESIMPULAN}

Sebagai kesimpulan, unsur gaya bahasa suspens yang banyak digunakan pengarang di dalam pemaparan peristiwa magis yang terdapat dalam Hikayat Marakarmah ini berjaya menerbitkan kesan emosi hairan khalayak. Proses transformasi emosi yang berlaku kesan daripada khalayak menikmati karya sebagai objek estetik memberikan kesan keindahan dan pengalaman estetik yang cukup menghiburkan sehingga memancing rasa lega pada jiwa khalayak. Hal ini sangat bertepatan dengan pernyataan karya sebagai alat terapi jiwa. Hal ini adalah kerana, bagi teks hikayat elemen magis ini diadun dengan cukup sempurna bagi memenuhi objektif karya sebagai alat terapi kepada jiwa. Selain memenuhi fungsi karya sebagai hiburan, karya ialah medium penyembuhan yang terbaik apabila watak-watak di dalam karya serta emosinya disebatikan dengan perwatakan dan emosi khalayak. Hasilnya kesan rasa yang dibawa pengarang tercapai apabila emosi khalayak diseimbangkan dengan gaya bahasa suspens, hiperbola, personafikasi dan dialog. Pengarang berjaya mengadunkan penceritaan dengan baik apabila khalayak bertindak balas memberikan kesan emosi daripada penceritaan yang dibawa. Bagi teks klasik yang mempunyai pengaruh Hindu-Islam, unsur magis yang dibawa sememangnya sebagai medium terapi terbaik berbentuk hiburan kepada khalayak.

\section{RUJUKAN}

Abu Bakar Hamid. (peny.) (2016). Hikayat Si Miskin. Kuala Lumpur: Dewan Bahasa dan Pustaka.

Abd. Halim Ali. ((2010). Konsep Estetika Bersepadu: Terapan dan Analisis Terhadap Karya-Karya Puisi Ahmad Kamal Abdullah: Tanjong Malim, Perak: Universiti Pendidikan Sultan Idris. 
Abd. Halim Ali. (2006). Iktisar Teori dan Kritikan Sastera Barat dan Malaysia: Selangor: ELPOS Print Sdn. Bhd.

Harun Jaafar. (2009). Wacana Kesusasteraan Melayu Klasik. Tanjong Malim, Perak: Universiti Pendidikan Sultan Idris.

Harun Mat Piah et al., (2006). Kesusasteraan Melayu Tradisional. Kuala Lumpur: Dewan Bahasa dan Pustaka.

Hashim Awang et al., (1985). Mendekati Kesusasteraan Melayu. Selangor: Penerbit Fajar Bakti Sdn. Bhd.

Hashim Awang (1989). Novel Hikayat: Struktur Penceritaan Melayu. Selangor: Penerbit Fajar Bakti Sdn. Bhd.

Hairul Anuar Harun. (2017). Estetika Kerohanian dalam Seni Kata Lagu S. Amin Shahab: Tanjong Malim, Perak: Universiti Pendidikan Sultan Idris.

Kamus Dewan Edisi Keempat. (2005). Kuala Lumpur: Dewan Bahasa dan Pustaka.

Muhammad Haji Salleh. (2006). Puitika Sastera Melayu. Kuala Lumpur: Dewan Bahasa dan Pustaka.

Muhd Mansur Abdullah. (2007). Prosa Tradisional Melayu. Pulau Pinang: Goal Intelligent Publishing Sdn. Bhd.

Nordiana Hamzah. (2014). Evolusi Emosi Zaharah Nawawi. Tanjong Malim, Perak: Universiti Pendidikan Sultan Idris.

Noriah Taslim. (1993). Teori dan Kritikan Sastera Melayu Tradisional. Kuala Lumpur: Dewan Bahasa dan Pustaka.

Nordiana Hamzah. (2014). Evolusi Emosi Zaharah Nawawi: Tanjong Malim, Perak: Universiti Pendidikan Sultan Idris.

Sohaimi Abd. Aziz. (1998). Rasa Fenomenologi: Penerapan Terhadap Karya A. Samad Said. Kuala Lumpur: Dewan Bahasa dan Pustaka.

Sohaimi Abd.Aziz. (2014). Teori dan Kritikan Sastera Edisi Kedua. Kuala Lumpur: Dewan Bahasa dan Pustaka. 